\title{
PECULIARITIES OF INVESTMENTS MANAGEMENT IN AGRO-INDUSTRIAL COMPLEXES
}

\author{
Zarmik Melikyan \\ PhD student of the Armenian National Agrarian University, Armeniya
}

DOI: https://doi.org/10.31435/rsglobal_ijite/30062019/6528

\section{ARTICLE INFO}

Received 11 April 2019

Accepted 12 June 2019

Published 30 June 2019

\section{KEYWORDS}

favorable investment environment, agro-industrial complex, food production, efficient investment policy, intergroup interests

\begin{abstract}
Investment policy has its peculiarities in agro-industrial complexes. The article analyzes the factors to formation of a favorable investment environment in the food industry, considering combined interests of agricultural, industrial and service organizations, stimulating the investing activity and providing efficiency of investment policy in agro-industrial complexes.
\end{abstract}

Citation: Zarmik Melikyan. (2019) Peculiarities of Investments Management in Agro-Industrial Complexes. International Journal of Innovative Technologies in Economy. 4(24). doi: 10.31435/rsglobal_ijite/30062019/6528

Copyright: (C) 2019 Zarmik Melikyan. This is an open-access article distributed under the terms of the Creative Commons Attribution License (CC BY). The use, distribution or reproduction in other forums is permitted, provided the original author(s) or licensor are credited and that the original publication in this journal is cited, in accordance with accepted academic practice. No use, distribution or reproduction is permitted which does not comply with these terms.

Agro-industrial complexes have a special impact on the formation of an investment environment, as they operate in a branch chain of economic activities, including the production, processing and sale of agricultural products. Nevertheless, the investment process simultaneously affects both the real sector of the economy (agriculture, food production processing) and the sphere of services (trade, banking), forming a special agro-industrial interconnected investment environment. ${ }^{1}$ In this case, the results of the functional branches activity is directly appearing in one economy chain and having unique driving force, forming the effect of inter sectorial influences on each other (see Figure 1).

The food industry is closely connected with formation of such an environment of investment sector, as it acquires a number of economic and organizational benefits under the conditions of the agroproduction complex. First of all, food production taking benefits from economic management, when agriculture and food processing operate within a system with technologically interconnected scheme. Investment activity in this case becomes targeted to the field of agricultural production, which results in a raw material base for the processing industry. Consequently, the agro-industrial system has a common investment interests, that are formed within the framework of agricultural and industrial interconnection. In this case, corporate governance approaches are becoming increasingly common in agro-industrial complexes, which has its own particular impact on the sectoral investment environment. ${ }^{2}$

\footnotetext{
${ }^{1}$ Мычка С.Ю., Мартынов С.В. Приоритетные направления развития предприятий АПК на основе стратегии импортозамещения // Закономерности развития региональных агропродовольственных систем. 2015. Т.1. №1. C. 103-104.

${ }^{2}$ Смольянинова И.В., Ахмедов А.Э. Обеспечение конкурентоспособности предприятий АПК на основе инвестиций в инновационные изменения // Инновационное развитие Сборник научных статей по материалам международной научно-практической конференции. 2015. - стр. 380-382.
} 


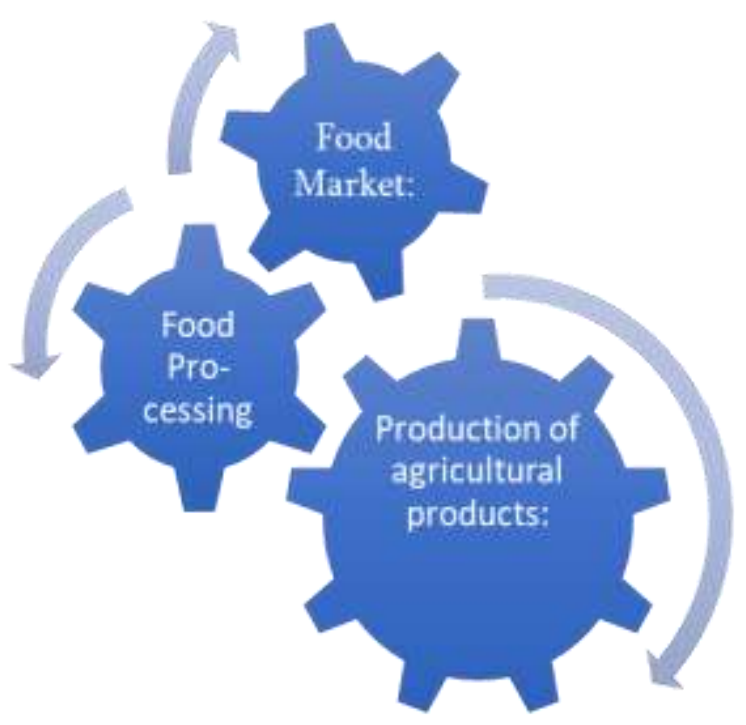

\section{Fig. 1. Formation of the Investment Environment in Agro-Industrial Complexes with the Branch} Sector Interconnection ${ }^{l}$

The organizations, included in agro-industrial complexes are trying to control the risks of business, considering the scope of their overall approach to prevention. At the same time, the risks of trade in food industry are shaped not only in the agricultural sector (unfavorable weather conditions, decline in agricultural production, failure in qualitative characteristics of the issuing product), but also in food processing companies (weakening of financial stability, losing competitive positions in the market, deflation, etc.). ${ }^{2}$ Therefore, there is a need to manage sectoral risks as much as possible by common efforts and even to equally allocate risk insurance compensation costs in the areas of agriculture and food processing.

One of the advantages of the agro-industrial complex is the provision of competitive positions in the agro-market. In such situations, intergroup interests require not only market-based, but also transfer-rates to apply to technology-based organizations. If market prices connected with the balance of supply and demand and thus regulate the market, the transfer pricing does not considering demand and supply off balance and is primarily targeted at the consolidated economic interests of the related entities, such as: mutual assistance with financial resources, tax planning, and improvements in financial performance in intra-group businesses with transference offerings for economic units.

Consequently, the use of transfer inter-group prices between the food industry enterprises included in the agro-industrial complex creates a specific agro-market sphere, where the motivation prices are used as a result of internal conditionality, which in turn, affects the formation of an investment environment. $^{3}$

Parallel to price motivation policy, in agro-industrial complexes an environment of support for innovation projects is also being developed. Thus, food processing companies involved in such complexes are interested in implementing innovation in the agrarian sector, applying the latest technologies in agricultural production and spending production. In its turn, the business sector of the agrarian sector is eager to increase sales of agricultural products, is interested in the increase in the demand for food processing companies, which is feasible with the introduction of innovative products in the food industry. Consequently, innovation investment projects are more actively invested in agroindustrial complexes, pursuing mutually beneficial economic goals. ${ }^{4}$

Intragroup interests in the food industry complex also require a harmonious allocation of financial resources for production organization. Specifically, it is manifested in the areas of attracting

\footnotetext{
${ }^{1}$ Composed by author.

2 Баутин В.М. Диверсификация в системе устойчивого развития предпринимательских структур АПК // Синергия. 2015. № 1. С. 60-65

${ }^{3}$ Смольянинова И.В., Ахмедова О.И., Мамедов Ф.М. Формирование и развитие агропродовольственного рынка // Территория науки. 2013. № 4. стр. 83-89.

${ }^{4}$ Давыдова Е.Ю. Проблемы управления инновационно-инвестиционной деятельностью транснациональных корпораций // Синергия. 2016. № 2. стр. 56-62.
} 
credit resources, formulating insurance policies, retraining finance, technical re-equipment, and marketing services. In this case, the industrial sector has its resource support to the agrarian sector, when the latter is forming a lack of funding sources in that direction. ${ }^{1}$

In addition to inter-farm mutual assistance, food procurement organizations in the agroindustrial complex also provide institutional support to each other. Thus, when forming a consolidated profit in the food industry, the agricultural sector seeks tax privileges, and the manufacturing sector is taxable, which ultimately brings to the tax burden of the agro-industrial complex. In this regard, the tax planning process is activated in the food industry, the purpose of which is to obtain tax exemptions both in agricultural production and in the processing industry.

Institutional support is most active in the financing of organizations listed in the food industry complexes when organizations with high liquid assets are provided with preferential loans, leasing services from commercial banks, which are then redirected to the intrinsic interests of other entities included in the agro-industrial complex.

In the case of centralized governance, the state has "above" institutional impetus for balancing the macroeconomic investment environment in terms of tax reforms, free movement of investment profits, investment capital protection, and investment competitive environment.

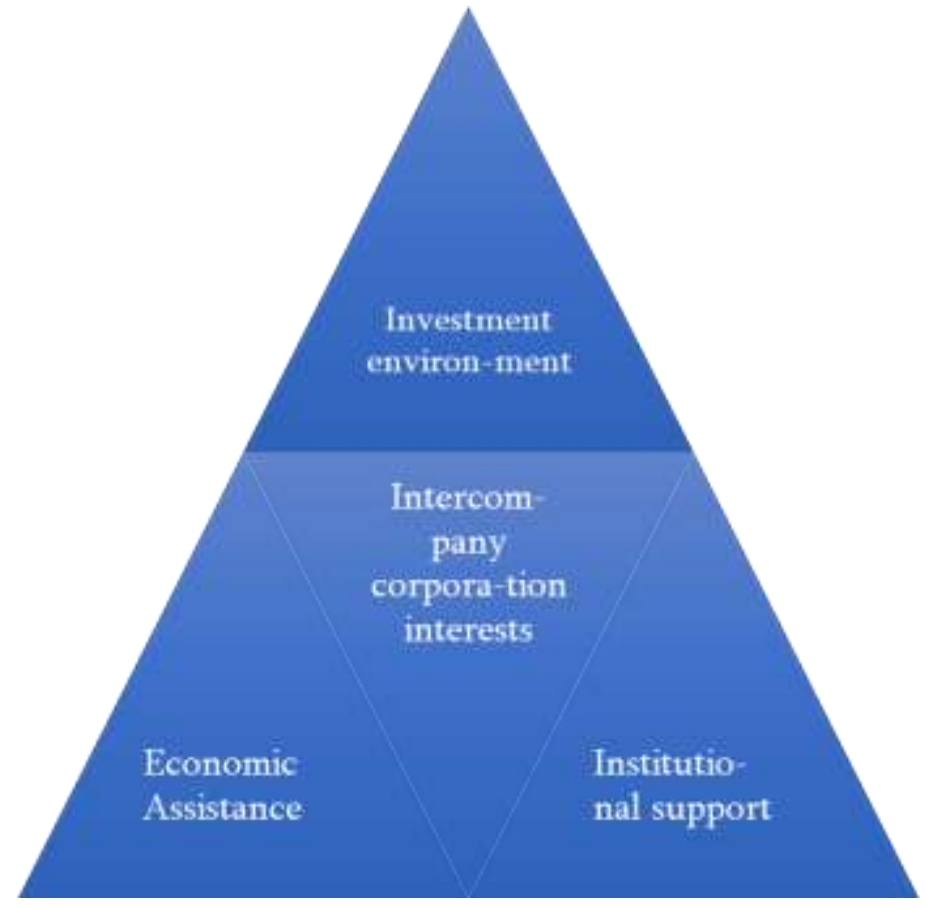

Fig. 2. Creating a favorable investment environment in the context of corporate governance. ${ }^{2}$

The "bottom" regulation of the investment environment related to the agrarian system is moving from the macroeconomic environment to the business environment, which is the conecting the branch of the economy, when regulating functions are mostly derived from the interests of the corporate, rather than the centralized corporate group. Consequently, in the investment environment, a corporate spirit is formed around the food industry, it leads to corporate governance at the enterprise level, following the inner interests of organizations involved in the complex. In this case, the motivation for economic and institutional support for the formation of qualitative characteristics of the business environment is the intrinsic corporate interest, that is in the center of the management system (see Figure 2).

Experience shows, that the investment environment acquires qualitative new features when it is viewed within the business-market framework. Thus, food security organizations, which are rooted in corrosive systems, when they direct their corporate governance goals to corporate interests, then favorable conditions for investment activities are activated.

\footnotetext{
${ }^{1}$ Клюшин В.В., Баулина О.А. Оптимизации движения инвестиционных ресурсов в условиях нестабильности внешней среды. ЮНИТИ, М, 2015, стр. 25-27

${ }^{2}$ Created by author.
} 
Conclusions. Corporative goals lead to the fact, that agro-industrial complexes in the food industry create an investment market, based on the combination of branches of the economy, which can implement its regulatory functions by implementing a number of corporate governance principles in the implementation of investment efficient sector policies.

First. rather than a single entity, the managerial decisions of the financial and economic substitute for the common interest of agrarian and industrial organizations involved in the complex.

Secondly, the formation of a consolidated profit formulation through incomplete compromises, when corporate profits are based on interest in the food industry rather than market, but transfer rates, thereby allowing the profit generation capabilities to be transmitted through interconnected ways from intra-enterprise organizations to one another

Third, removal of administrative barriers, when corporate governance approaches are mitigated as much as possible by regulatory barriers to business relations in the food industry (agriculture, processing, commerce) and thereby creating a favorable investment climate

Fourth, managerial collegial decision-making, when the decision-making process is based on a single basis, and thus collapses between inter-organizational and pre-conflict interests, reducing sectoral investment risks. 